\title{
Re-Os Ages for the Kourki Porphyry Cu-Mo Deposits, North West Niger (West Africa): Geodynamic Implications
}

\author{
Mallam M. Hallarou, Moussa Konaté, Akinade S. Olatunji, Yacouba Ahmed, Felicia F. Ajayi, and \\ Rasheed M. Abdul
}

\section{ABSTRACT}

The study area is located at the southern end of the Gorouol greenstone belt, northwestern Niger. This region contains significant deposits of Copper and Molybdenum hosted in intrusive rocks metamorphosed in the green shale facies. This deposit was previously considered a porphyry system of Copper (Cu) and Molybdenum (Mo) without having been the subject of advanced research. The objective of this study is to confirm or refute this hypothesis and to date the mineralisation in an absolute manner in order to readjust the mineralising episode in the history of the West African Craton. The methodology used within the framework of this study is the isotopic dating by the Re-Os method carried out on the pyrites of the host rock. The results of this analysis give an age range between $2158 \pm 50 \mathrm{Ma}$ and $2110 \pm 51 \mathrm{Ma}$ for the $\mathrm{Cu}$-Mo mineralisation. This age range represents the West African Craton scale to an episode of magmatic accretion. During this accretion, the subduction phenomena between the Crusts (Oceanic and Continental) would have been favourable for the formation of the $\mathrm{Cu}$ and $\mathrm{Mo}$ mineralisation of Kourki.

Keywords: $\mathrm{Cu}-\mathrm{Mo}$ mineralization, Gorouol greenstone belt, magmatic accretion, West African craton.
Published Online: July 21,2020.

ISSN: $2506-8016$

DOI: $10.24018 /$ ejgeo.2020.1.4.43

\section{M. Hallarou*}

Pan African University of Life and Earth Sciences Institute (PAULESI), University of Ibadan, Nigeria.

Abdou Moumouni University of Niamey, Niger.

(e-mail: mamane.hallarou $@$ gmail.com) M. Konaté

Abdou Moumouni University of Niamey, Niger.

(e-mail: konate.moussa@gmail.com) A. S. Olatunji

Pan African University of Life and Earth Sciences Institute (PAULESI),

University of Ibadan, Nigeria.

(e-mail: akinadeshadrech@yahoo.com)

Y. Ahmed

Abdou Moumouni University of

Niamey, Niger.

(e-mail: ylibore@ ${ }^{\circledR m a i l . c o m) ~}$

F. F. Ajayi

Pan African University of Life and Earth Sciences Institute (PAULESI),

University of Ibadan, Nigeria.

(e-mail: felifanmi @ gmail.com)

R. M. Abdul

Pan African University of Life and Earth Sciences Institute (PAULESI), University of Ibadan, Nigeria.

(e-mail: rmabdu1009@gmail.com)

*Corresponding Author

\section{INTRODUCTION}

The dating of mineralisation in West Africa has often been obtained relatively to the absolute ages of the host rocks. In addition, studies on the genesis of copper deposits are generally limited by the lack of suitable minerals to directly determine the age of mineralisation. In Niger, the most commonly used methods for dating mineralisation of these deposits are $\mathrm{U}-\mathrm{Pb}, \mathrm{Pb}-\mathrm{Pb}, \mathrm{K}-\mathrm{Ar}, \mathrm{Rb}-\mathrm{Sr}, \mathrm{Sm}-\mathrm{Nd}$, among others. These most commonly applied techniques do not provide an age for the mineralisation itself. The age of mineralisation formation is generally deduced from the moment of magmatism, tectonics, metamorphism and alteration. However, it is still difficult to determine the age of mineralisation in a deposit that records evidence of multiple tectonic and magmatic events. Accurate dating of the mineralisation age is crucial to determining the genesis and viability of the deposit. With the progress made in Re-Os dating on molybdenite [61] or in $\mathrm{Rb}-\mathrm{Sr}$ dating on sphalerite [10], [11], [42], [45], it is possible to obtain an age directly on mineralisation from one or a series of minerals corresponding to the mineralisation phase of interest. These isotopic dating techniques make it possible to obtain information on the age, the chronology and/or the lifespan of the hydrothermal activity, by coupling them for example with dating techniques of the surrounding and alterations (K-Ar, $\left.\mathrm{U}-\mathrm{Pb},{ }^{40} \mathrm{Ar} /{ }^{39} \mathrm{Ar}\right)$. 
The Kourki Copper ( $\mathrm{Cu}$ ) and Molybdenum (Mo) mineralisation is located in the Birimian formations in the Northwestern part of Niger. This mineralisation was discovered by Machens [34] during the general prospecting of the liptako. The tonnage of this $\mathrm{Cu}-\mathrm{Mo}$ mineralisation has been estimated at $160 \mathrm{Mt}$ with a grade of $0.004 \mathrm{~g} / \mathrm{t} \mathrm{Cu}$ and $0.01 \mathrm{~g} / \mathrm{t}$ [28].

Previous works done on the Kourki mineralisation focused on the geological characteristics, alterations and geochemistry of the soil. These studies have suggested that the Kourki mineralisation is a porphyry deposit, but the mechanism of implementation of this mineralisation is still unknown in the context of the complex geological and magmatic evolution of the Kourki region. Based on the aforementioned, this study presents the data on the age of pyrite through the Re-Os method to limit the age of establishment of the Kourki mineralisation in order to readjust the mineralising episode in the history of the West African Craton.

\section{STUDY AREA}

\section{A. Geological Setting}

The West African Craton (WAC) is made up of an Archean-Paleoproterozoic basement. It is divided into the Reguibat Rise ridge and the Man ridge (fig. 1). These ridges are covered in discontinuity by the Neoproterozoic to Holocene sedimentary sequences. The Man Ridge of which the study area is located is subdivided into two areas: the Kénéma-Man Archean domain $(3.5 \mathrm{Ga})$ and the BaouléMossi Palaeoproterozoic domain (2.3-1.8 Ga) [16]. The Kénéma-Man domain consists of a granito-gneiss complex and a granulitic meta-gabbro [63]. The Baoulé-Mossi domain is made up of Birimian metasedimentary and metavolcanic sequences formed around $2.3 \mathrm{Ga}$ (according to [16], [44]). The formation of the Baoule Mossi domain was intruded by a suite of TTG (Tonalite-Trondjhemite-Granodiorite). The establishment of these TTGs occurred at $2.2 \mathrm{Ga}, 2.16-2.13 \mathrm{Ga}$ and 2.1-2.07 Ga concomitant with the deformation of the Birimian greenstone belt [21]-[23], [32].

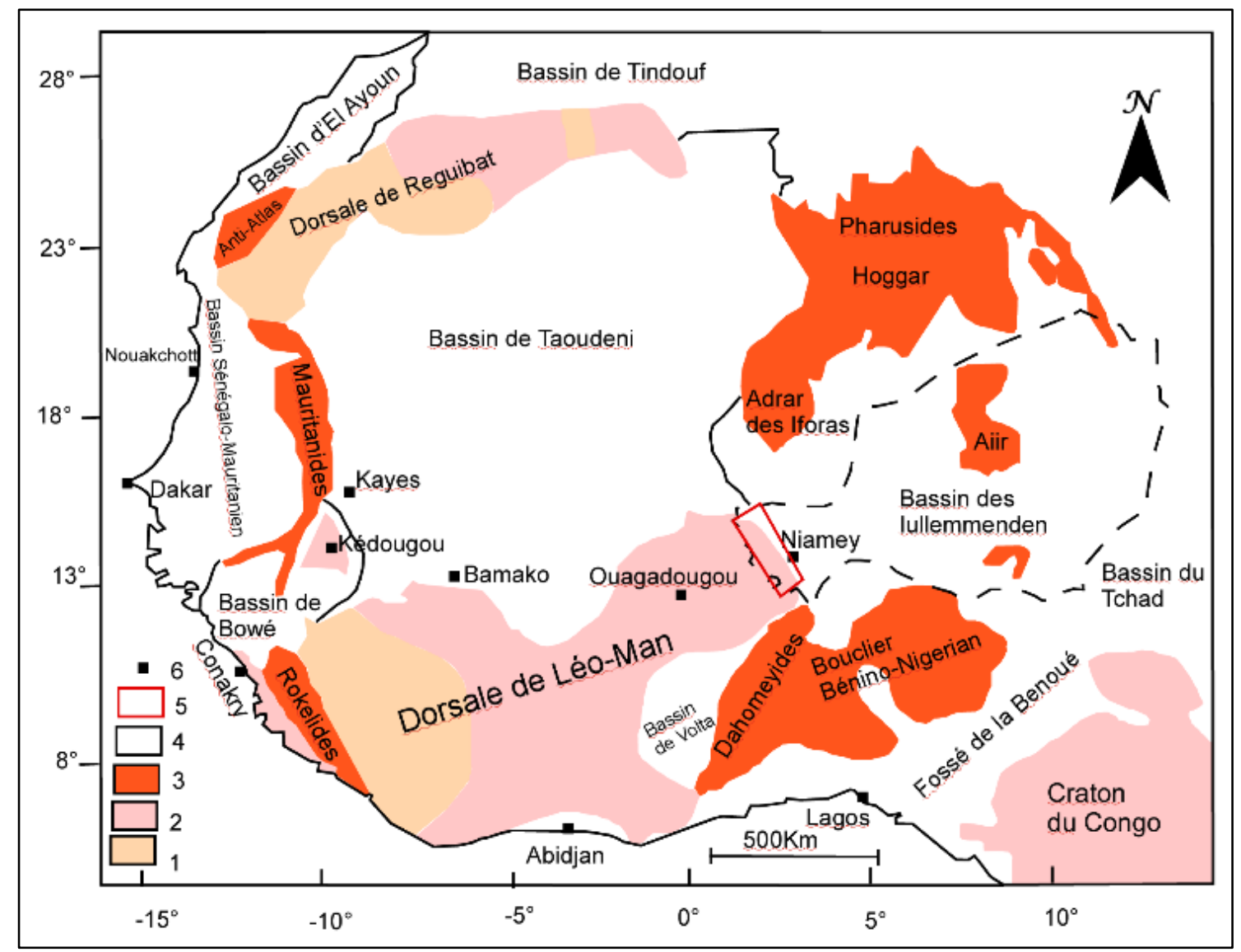

Fig. 1. Simplified geological map of West Africa (from Trompette [65], modified), showing the Liptako area. 1: Archean; 2: Birimian; 3: Pan-African mobile areas; 4: Sedimentary basins of neoproterozoic to paleozoic age; 5: Study area; 6: cities.

This granitic suite is intrusive both in the Birimian formations and in the granitoids of the TTG suite. Their implementation period is between 2150 and $1950 \mathrm{Ma}$ [12], [32], [33].

In the Gorouol belt, the dikes, veins, and granitic formations rich in potassium and pyroxenite-gabbro are invaded by granitoids and therefore predate their establishment [66][68]. Northwest and Northeast dolerite dykes crossing the WAC were probably set up during the final crust rupture of the supercontinents at $1.4-1.2 \mathrm{Ga}$ [76].
The group of Tarkwaian or higher Precambrian [35] overlaps the Birimian formation [25], [31], [39]-[41]. This group is dated 2194-2132 Ma by the U-Pb method on detrital zircon [15].

\section{B. Local Geology}

The Nigerien liptako occupies the northeast end of the Man Ridge including the Baoulé-Mossi area. It is bounded to the north by the Taoudeni Basin and to the east by the surface formations of the Iullemmeden Basin. Based on the U-Pb, $\mathrm{Rb}-\mathrm{Sr}$ and $\mathrm{Sm}-\mathrm{Nd}$ isotopic data, the study area (Nigerien 
liptako) is considered an old crustal growth area of $2.1 \mathrm{Ga}$ [59]. In the Nigerien liptako, the age reported on various granitoids is between $2137 \pm 126$ and $2188 \pm 12 \mathrm{Ma}$ [59]. The synthesis of the work carried out shows that the base of the liptako, of Paleoproterozoic age, is made up of granitoid plutons alternating with belts of green rocks [17], [26], [34]. This alternation is overcome by the sedimentary cover which includes infracambrian, tertiary (post-Eocene) formations of the Continental terminal, and quaternary. The granitoid plutons are composed mainly of granites and TTG (Tonalites, Trondhjémites, Granodiorites) (Fig. 2). Pluton placement is associated with metamorphism and deformation in a context of global NE-SW shortening [47], [61]. The greenstone belts are made up of metasediments (clay shales, quartzitoschists, micaschists), sedimentary meta-volcanoes (greywackes), meta-volcanoplutonic [1], [3], [26], [58], [60], tuffs and rhyolitic breccias. They also include pyroxenites, amphibolites, epididites, chloritoschists, metabasalts, and metagabbros, of NNE-SSW orientation. The present study was carried out in the south of Gorouol Greenstone belt (Fig. 2).

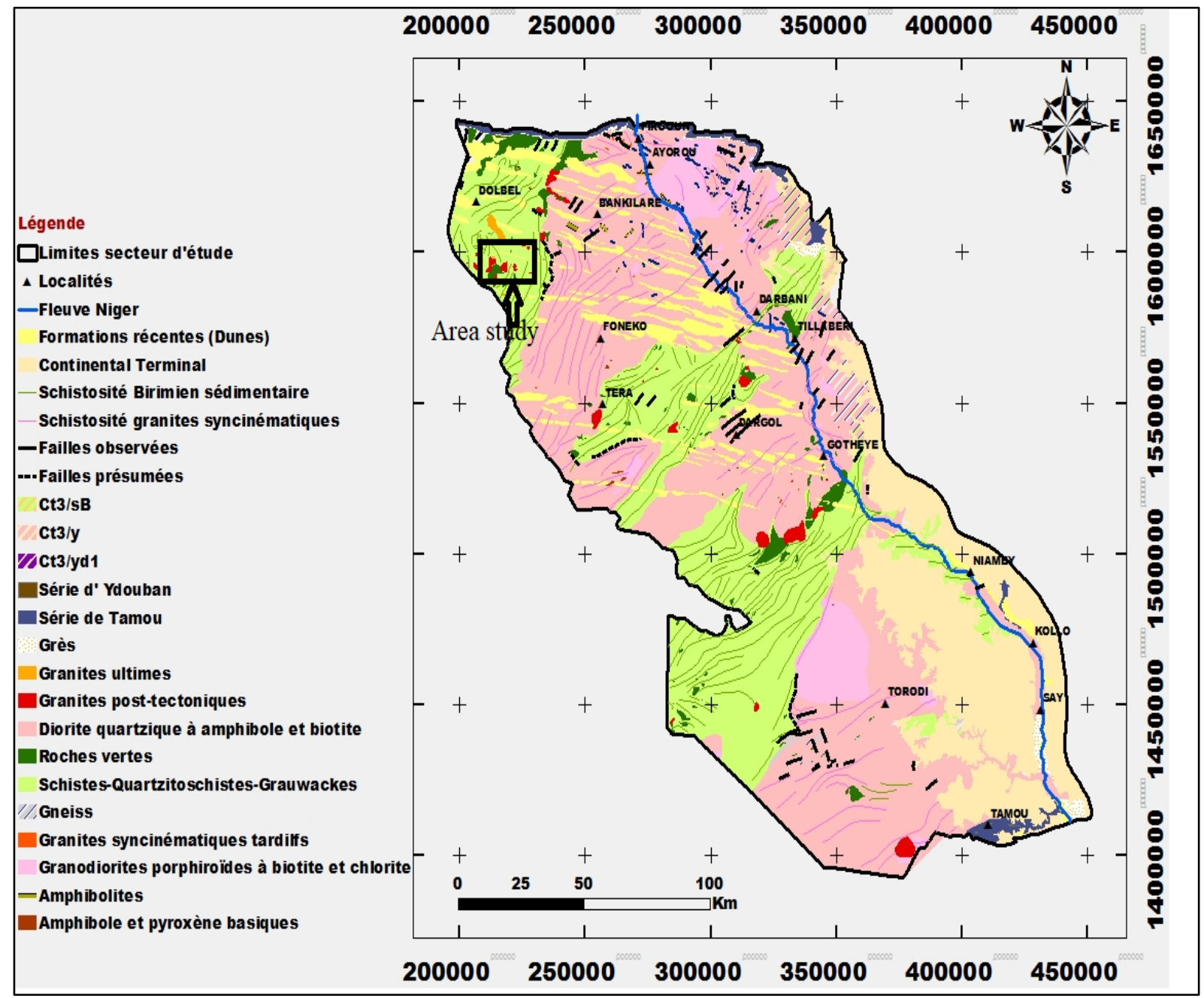

Fig. 2. Location Map of Study Area

\section{SAMPling AND ANALytical Methods}

A total of 5 thin and polished sections were produced at the Center for Geological and Mining Research (CGMR) in Niger. The samples analysed are the subject of observations using a polarizing microscope at the laboratory of the Abdou Moumouni University of Niamey Geology department. The objective of this step is to determine the nature of the lithology, the mineral associations and the alteration and mineralisation assemblages.

About dating, 5 samples of pyrites from granodiorite were analysed in the Nancy laboratory (France) using the Rhénium Osmium (Re-Os) isotopic method. This analysis was carried out on mono-mineral powders. The minerals were picked by hand and ground in an agate mortar. The osmium and rhenium were extracted chemically in the cleanroom of Center for petrographic and Geochemical Research (CPGR) at Nancy laboratory in France. About $0.3 \mathrm{~g}$ of each purified separated mineral was enriched with ${ }^{190} \mathrm{Os}$ and ${ }^{185} \mathrm{Re}$ and digested in a Carius tube at $230{ }^{\circ} \mathrm{C}$ for 24 hours in a $3: 1$ solution of $\mathrm{HNO}_{3}: \mathrm{HCl}$. After this step, Os was separated by liquid-liquid extraction and purified by microdistillation. The rhenium was separated from the residue using an anion exchange resin. The osmium analysis was carried out by negative thermal ionization mass spectrometry (NTIMS) using a Finnigan MAT 262 instrument at CPGR. This was equipped with an electron multiplier and counting electronics ions and an oxygen leak valve. Rhenium analysis was carried out by ICP-MS quadrupole Elan 6000 at Rock and Minerals Analysis department (RMAS) (CPGR, Nancy). 


\section{RESUlts AND Discussion}

\section{A. Characteristics of Mineralisation}

Kourki's molybdenite (Mo) and copper ( $\mathrm{Cu}$ ) mineralisation is disseminated in a schist of sedimentary origin enclosed in porphyry granodiorites intruding the Gorouol green belt [34]. This schist is chopped by veins oriented in all directions. The mineral paragenesis of the Kourki deposit is of the molybdenite-chalcopyrite-chalcosine-malachite-pyrite-

sphalerite type. Pyrite is encountered mainly on schistgranitoid contact. The entire volcano-sedimentary region of the study area is affected by epi-hydrothermal quartz inflows of volcanic origin. These epi-hydrothermal activities have also affected the granitoid massifs (granodiorite), the contact zones between volcanic rocks and shales, and even the sedimentary series. A multitude of quartz veins and veins crack all of these formations. These quartz veins are also carriers of mineralisation in the Kourki region.

Molybdenite is in the form of aggregates of elongated crystals that can be disseminated in the gangue. Molybdenite appears to the unaided eye as greyish blue with a distinct bluish tinge, and is very often disseminated in a disorderly fashion. It is also found in the form of a fly in the veins of grey (smoky) quartz. Molybdenite is sometimes disseminated in granodiorites. However, in the field, when the molybdenum content is high, the quartz takes on a metallic luster (Fig. 3D).

Chalcopyrite and pyrite appear in large crystals. Pyrite also appears in the form of fine aggregates, elongated or coarse xenomorphs rarely subautomorphic (Fig. 3E). This sulphide is either disseminated in the rock, or filling the intergranular spaces in the quartz vein. These quartz veins can be calcite veins or be composed entirely of pyrite (Figs. 4G, 4H). These quartz veins also include small amounts of molybdenite, chalcocite, bornite, azurite, gold, chlorite and epidote. Chalcopyrite is the dominant sulphide and occurs as anhedral crystals interspersed with pyrite in quartz veins (Fig. 3C). Molybdenite is rare and generally has a hexagonal shape, and it occurs in the form of aggregates interspersed with chalcopyrite (Fig. 3D). Pyrite is generally in the form of hypidiomorphic or xenomorphic crystals which are interspersed with galena and sphalerite in quartz veinlets (Figs. 3E, 3F). The largest crystals are fractured (Fig. 3C), however, the small crystals are often automorphic and intact. Analysis of the slides under the microscope also revealed the presence of gold in the Kourki mineralisation (Fig. 3A).

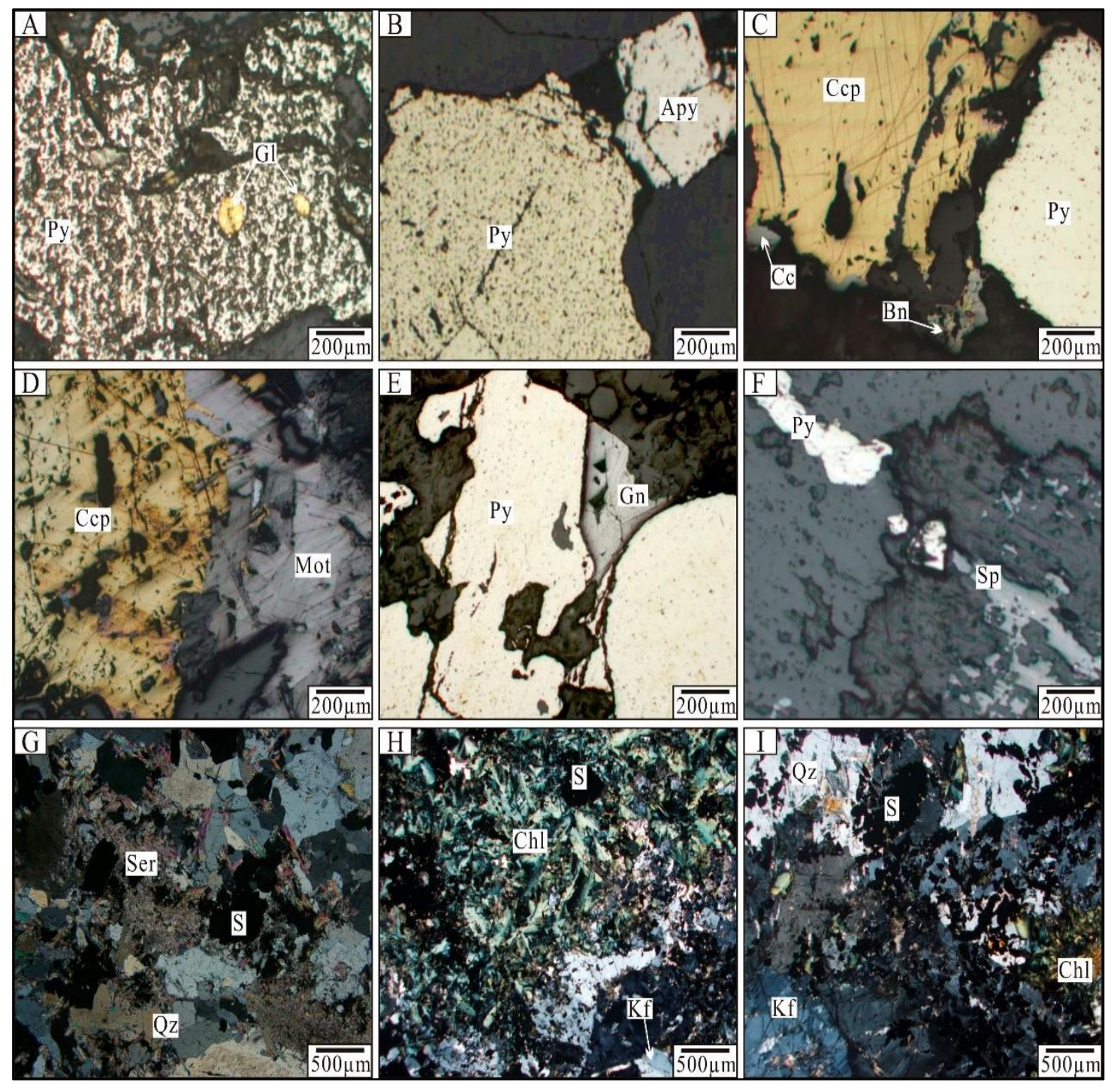

Fig. 3. Photomicrographs showing (A) Native gold in pyrite; (B) coexistence between pyrite and arsenopyrite; (C) assemblage of pyrite-chalcopyritechalcocite-bornite; (D) chalcopyrite-molybdenite assemblage; (E) pyrite and galena coexistence; (F) pyrite-sphalerite venule; (G) brecciation of rock wall; (H, I) chloritization and alteration in potassium feldspar of the rock walls. Abbreviations: Qz, quartz; Ser, sericite; Chl, chlorite; Kf, potassium feldspar; S, sulphide; Py, pyrite; Ccp, chalcopyrite; Gn, galena; Sp, sphalerite; Apy, arsenopyrite; Mot, molybdenite; Bn, bornite; Cc, chalcocite; Gl: gold. 


\section{B. Paragenetic Succession}

The paragenetic succession is essentially based on the textural relationships that exist between minerals. This was difficult to establish because the minerals do not always appear in the same polished section, and in many cases, they appear alone, isolated from other minerals; thus, the relationship between molybdenite with other minerals is not always clear. Based on this, four paragenetic stages for the Kourki deposit were proposed. Early stage: quartz $+\mathrm{K}$ feldspar \pm sulphides (molybdenite pyrite) \pm magnetite (Figs. 4A, 4B). This early stage is characterised by the modification of pre-existing minerals. Precipitation of quartz, potassium feldspar and magnetite began during the early stage. Sulphides during this stage including molybdenite and pyrite are limited.
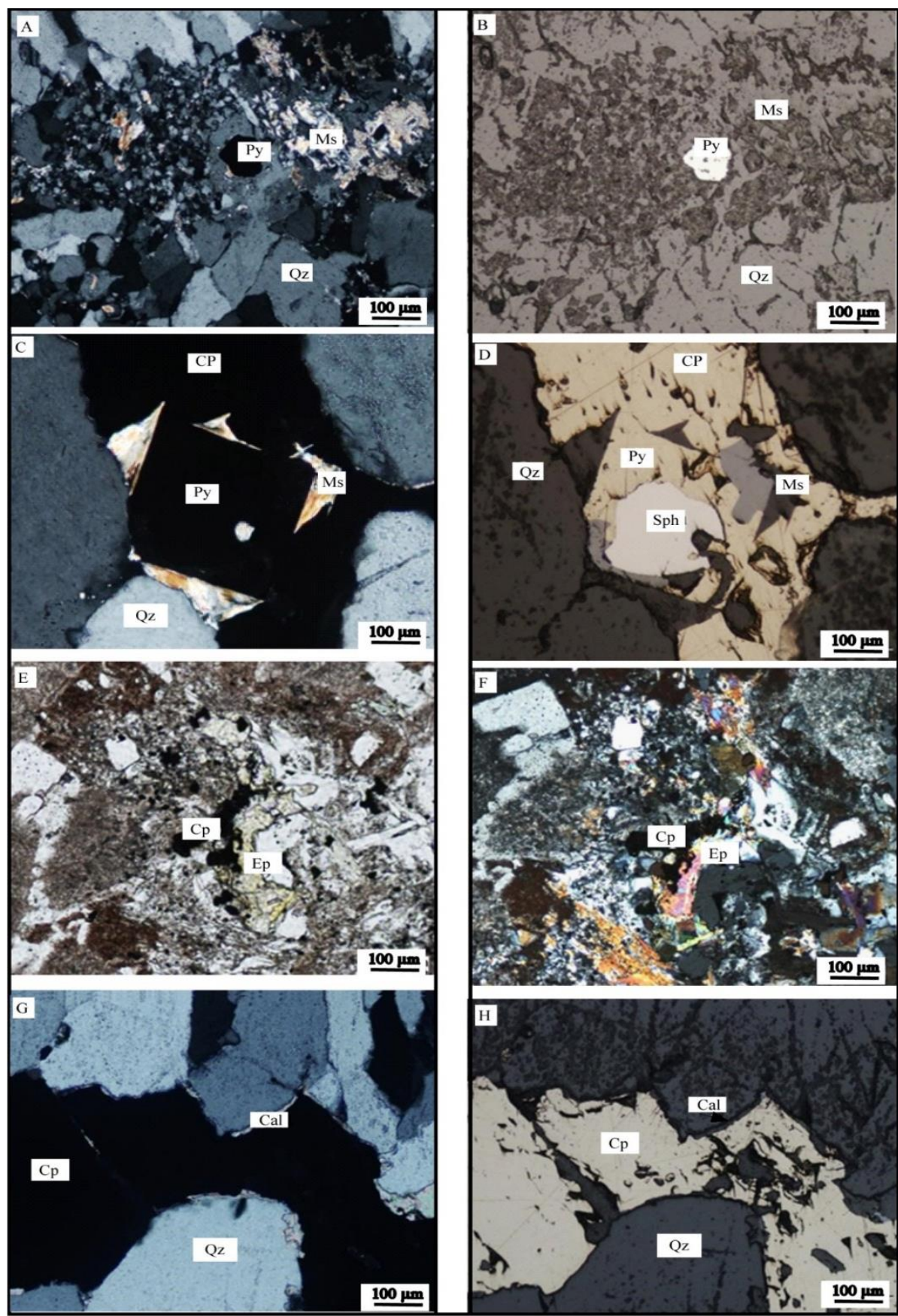

Fig. 4. Photomicrographs showing (A, B) the early alteration phase (Pyrite in the host in Analysed polarized light (APA) and reflected light (RL); (C, D) the mineralisation phase illustrating paragenesis of pyrite, chalcopyrite and sphalerite in Analysed polarized light (APA) and reflected light (RL); (E, F) stage with copper mineralisation showing the epidote associated with chalcopyrite in Analysed polarized light (APA) and reflected light (RL); (G, H) the last

stage of mineralisation showing a late calcite vein surrounded by idiomorphic quartz in Analysed polarized light (APA) and reflected light (RL). Abbreviations: Qz, quartz; Py, pyrite; Cp, chalcopyrite; Sp, sphalerite; Cal, calcite; Ep, epidote; Ms; muscovite. 
The presence of chalcopyrite inside the molybdenite crystals indicates a contemporary crystallization for the two elements. Pyrite seems to be the first to crystallize since it is cut by chalcopyrite veinlets. In some cases, pyrite, chalcopyrite and molybdenite are either disseminated in the matrix of the host rock, or in the veins of microcrystalline quartz. Chalcopyrite is often associated with pyrite, sphalerite and bornite. Native gold is found exceptionally in quartz veins intersecting granodiorite, and in association with molybdenite, chalcopyrite and calcite [49]. The combination of minerals such as chlorite, epidote calcite and the presence of streaks of quartz observed in Kourki granitoids attest that they underwent the effects of hydrothermal alteration (Figs. $3,4)$. Indeed, hydrothermal solutions play a big role and can explain the appearance of these minerals. Molybdenite is either isolated from quartz or associated with weathering minerals such as fluorite, carbonates, epidote and chlorite.

\section{Dating of $\mathrm{Cu}$-Mo Mineralisation}

The ${ }^{187} \mathrm{Os} /{ }^{188} \mathrm{Os}$ isotopic ratios of the samples analysed are very high and therefore very radiogenic. Since the samples analysed prove to be very radiogenic, it is therefore not necessary to use the isochronous method to obtain the age. The results of the measurements are presented in Table 1.

TABLE I: Re-Os DATA OF THE PYRITES FROM THE KOURKI CUPRIFEROUS DEPOSIT

\begin{tabular}{|c|c|c|c|c|c|c|c|c|c|c|c|}
\hline Samples & Phases & $\begin{array}{l}\text { Sample } \\
\text { mass (g) }\end{array}$ & $\begin{array}{l}\text { [Re] } \\
(\mathrm{ppb})^{1}\end{array}$ & $\begin{array}{l}{ }^{187}[\operatorname{Re}] \\
(p p b)^{1,2,3}\end{array}$ & $\begin{array}{l}{ }^{188} \mathrm{Os} \\
\text { total } \\
\text { (ppt) }\end{array}$ & $\begin{array}{l}\%{ }^{187} \mathrm{Os} \\
\text { Blanc }\end{array}$ & $\begin{array}{l}{ }^{187} \mathrm{Os} \\
\text { total } \\
\text { (ppt) }\end{array}$ & $\%{ }^{187} \mathrm{Os}^{* 5}$ & ${ }^{187} \mathrm{Os}^{*}(\mathrm{ppt})^{2,5}$ & ${ }^{187} \mathrm{Os}^{*} /{ }^{187} \operatorname{Re}^{1,2,3}$ & Age $(\mathrm{Ma})^{2,6}$ \\
\hline Kourki M1 & Pyrite & 0,30209 & 0,67 & $0,44 \pm 0,011$ & 0,09 & 68,1 & 15,75 & 98,20 & $15,46 \pm 0,55$ & $0,0370 \pm 0,0014$ & $2154 \pm 88$ \\
\hline Kourki M2 & Pyrite & 0,30278 & 1,76 & $1,13 \pm 0,012$ & 0,55 & 11,8 & 40,06 & 98,7 & $39,55 \pm 0,91$ & $0,0357 \pm 0,0010$ & $2110 \pm 51$ \\
\hline Kourki M3 & Pyrite & 0,30326 & 1,64 & $1,05 \pm 0,012$ & 0,46 & 14,1 & 38,82 & 98,8 & $38,36 \pm 0,83$ & $0,0372 \pm 0,0010$ & $2158 \pm 50$ \\
\hline Kourki M4 & Pyrite & 0,30735 & 9,52 & $5,98 \pm 0,023$ & 0,46 & 12 & 218,8 & 93,30 & $217,3 \pm 2,80$ & $0,0363 \pm 0,0006$ & $2142 \pm 36$ \\
\hline Kourki M5 & Pyrite & 0,30179 & 10,79 & $6,78 \pm 0,042$ & 0,56 & 10 & 247,1 & 99,40 & $245,6 \pm 3,10$ & $0,0362 \pm 0,0007$ & $2136 \pm 39$ \\
\hline
\end{tabular}

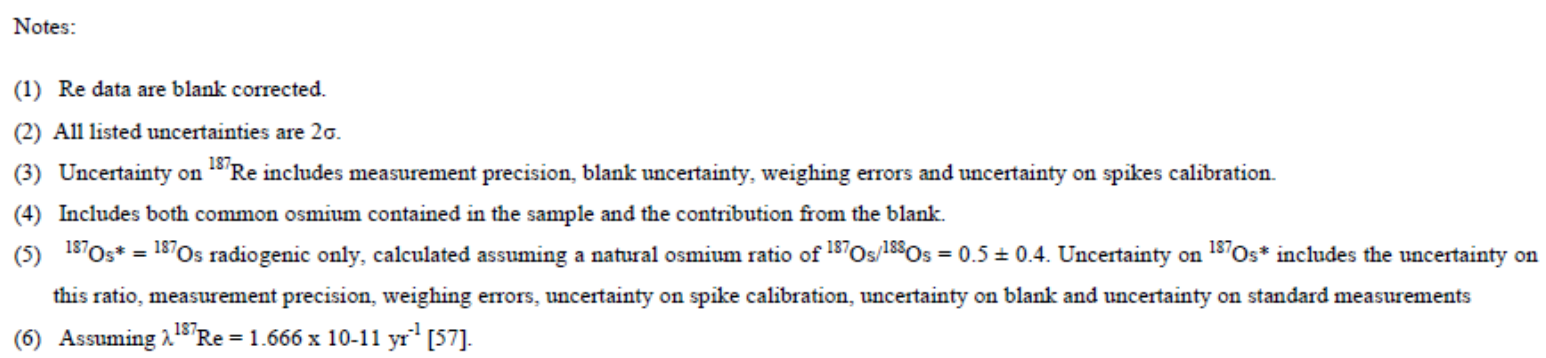

Based on this isotopic analysis, the ages obtained on the pyrites analysed vary from $2158 \pm 50 \mathrm{Ma}$ (Kourki M3 sample) to $2110 \pm 51 \mathrm{Ma}$ (Kourki M2 sample). This age shows a very varied gap. They are associated with relatively high uncertainties ranging from 36 to $88 \mathrm{Ma}$. This large uncertainty can be attributed to the low osmium and/or rhenium contents of the samples analysed. In fact, the lower the contents, the more difficult they are to measure and the more the measurement accuracy decreases [11]. The variability in ages, for its part, can be explained either by a heterogeneity in the distribution of rhenium and osmium in the pyrite crystals, or the Kourki mineralisation recording evidence of several phases of hydrothermal activity. This hydrothermal activity can cause zonation in the pyrite. This could change the composition of primary pyrite to give secondary pyrite. Indeed, according to Ranc [49], the secondgeneration pyrite crystals are zoned. However, if the composition of the hydrothermal fluid has varied between the crystallization of the heart of the pyrites and that of their overgrowths, it is possible that these have different rhenium and osmium contents, thus disturbing the dating. Likewise, if the heart and the overgrowths were formed at different times, they will have different ages and the calculated ages will have no geological significance. However, the ages obtained on the Kourki granodiorite pyrites did not allow the calculation of an average age with reasonable uncertainty. However, even though the weighted average ages of pyrite and molybdenum have not been calculated, petrographic observations suggest that the mineralising event for Molybdenum was after the Copper episode. Furthermore, even if the age-related uncertainty does not allow an absolute determination of the age of the Kourki $\mathrm{Cu}-\mathrm{Mo}$ porphyry formation, this age interval combined with the comparison of structural data corresponds to a second magma accretion episode in the history of the West African Craton (2200 to $2150 \mathrm{Ma}$ according to [5], [32], [33], [39], [63], [66], [67]) (Fig. 5).

The work of the Ministries of Mines of Niger [49] showed the presence of alteration that there would be a real zonation of the hydrothermal alteration of the rocks (at dream level K1). This zoning would be followed by the following alteration zones: phyllitic, argillic + phyllitic, argillic, propyllic and argillic, propyllic alteration, zoning similar to that which characterises copper porphyry deposits. The hydrothermal potassium alteration, localized in the central parts of the structures has been generalized at the Kourki site to the whole of the mineralised zone in the form of a neoblastesis of microcline detectable in thin section, and that the sulphides appear to be confined to the propylitic alteration zone (Fig. 6). The mineralisation presents a zonation. The central part of the deposit contains molybdenite and accessory chalcopyrite, while at the periphery, the ratio of the two mineralisations is reversed. The strategic geochemistry 
brought out, on the other hand, a succession of anomalous

halos in $\mathrm{Cu}+\mathrm{Zn} ; \mathrm{Zn}+\mathrm{Pb}$ around the main deposit [49].

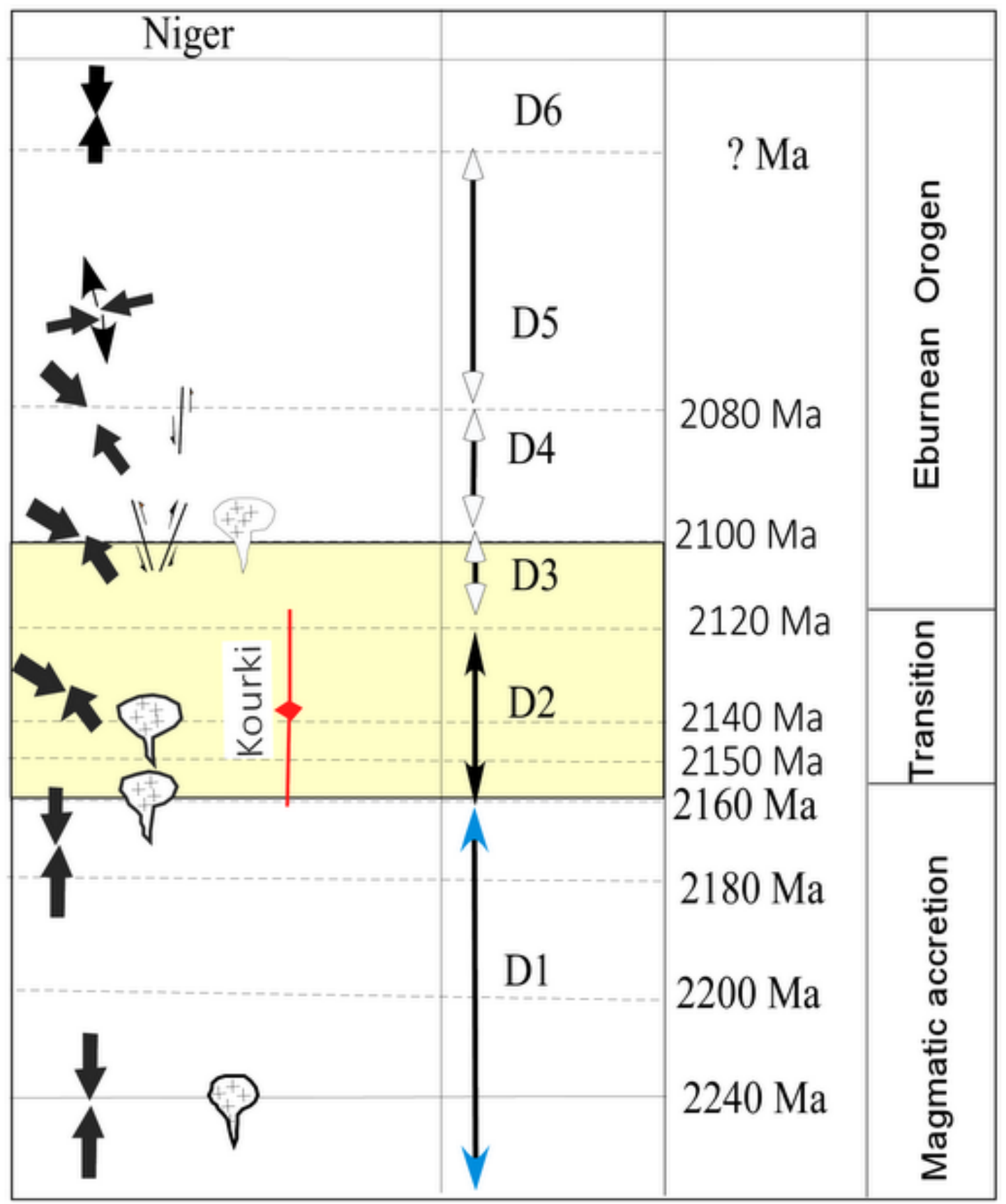

Fig. 5. Correlation between the Copper-Molybdenum deposit age obtained by Re-Os isotopic dating and the geodynamic evolution of the West African Craton in Niger.

According to Kusnir et al. [28], propylitic alteration is essentially characterised by the development of minerals enriched in $\mathrm{Ca}$ and $\mathrm{Mg}$ in igneous rocks; its paragenesis is the equivalent of the green shale facies. The essential minerals that make up the propylitic alteration: chlorite, epidote and calcite come from the alteration of mafic minerals, anorthitic component of plagioclase and minor complement of $\mathrm{H}^{+}$and $\mathrm{CO}_{2}$. The siliceous phase also constitutes the most important matrix which hosts the mineralisation of the sulphides of Mo and $\mathrm{Cu}$ at Kourki. In addition, it is important to underline that cracking played a capital role in the circulation of fluids expelled from the magma at the end of crystallization. This was induced either by the effect of tectonics, or by the hydraulic force following a drop in pressure such that it will have allowed the individualization of the magmatic aqueous phase at the origin of hydrothermal phenomena: a typical of late to post-solidus stages (in [14]). As for the distribution of mineral deposits, it directly depends on the mineralising fluids. However, results on the inclusion of fluid to address this part is not available at the moment.

Indeed, the Kourki granitoid presents a certain number of hydrothermal alterations with which the molybdiferous and copper mineralisations are associated. Thus, these types of hydrothermal alterations are specific to Kourki; these are linked to late-magmatic hydrothermalism of the porphyry type and not resulting from metamorphic transformations of green shale facies as it has been demonstrated in many plutons of the West African Craton [27], [30]. In addition, the paragenetic succession of weathering minerals associated 
with mineralisation observed in the structure is similar to porphyry.

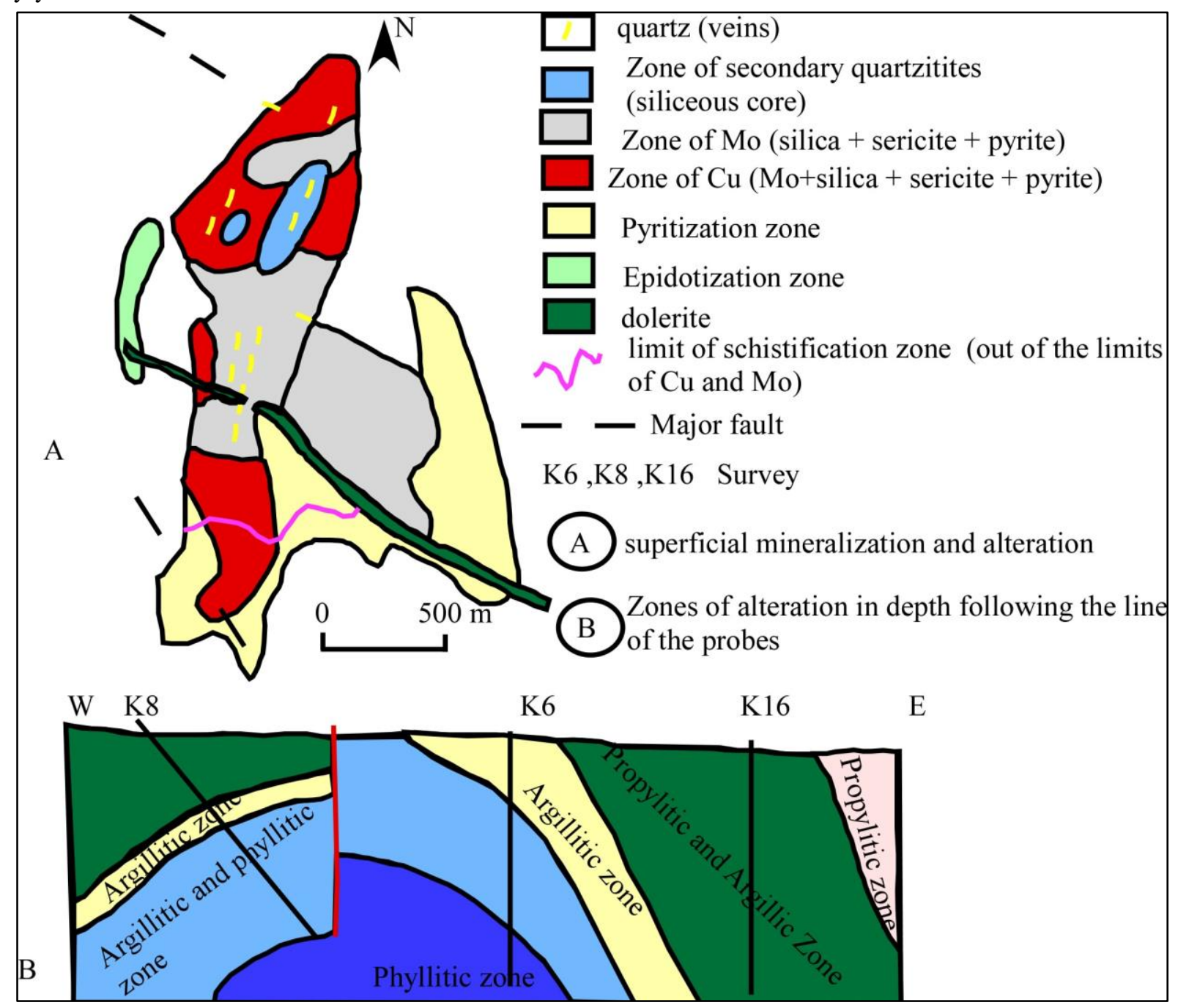

Fig. 6. Distribution of mineralisation and alteration zones (modified from Ranc [49]).

The geochemical signature of the host rock in the $\mathrm{Cu}-\mathrm{Mo}$ mineralisation at Kourki is similar to those already described in Niger in the Sirba belt [3], [48], [69]. Their composition varies from tholeiitic basalts and gabbros, representing the oceanic crust or oceanic plateaus [2], [59], to arc volcanism linked to bimodal calc-alkaline subduction. This composition is compatible with the evolution of the tholeiitic oceanic crust or the oceanic plateau towards juvenile volcanic island arcs, which formed between $~ 2200 \mathrm{Ma}$ and $2160 \mathrm{Ma}$ [3], [4], [59]. Concerning a possible relation of the molybdenum indices of Liptako with tectonic events, their linear arrangement along a North-West-South-East axis is parallel to the weak zone of Gao. From Black [6], this zone of weakness separates two different structural domains, interpreted as an active suture line. The axis on which the indices in the liptako are aligned (Fig. 7) has the same North-West-South-East orientation as the structures which characterise pan-African orogeny.

In terms of tectonics on the scale of West Africa, this zone of weakness is located at the limit of the West African craton and the Pan-African mobile zone, in a sub-meridian direction, which extends from the Gulf of Benin to North Africa. According to Reitchelt [50], a reactivation of the Birimian basement may have occurred during Pan-African orogeny, essentially resulting in ceasing tectonics of the indurated basement, which will favour the concentrations of molybdenite. In any case, it remains interesting to point out the spatial relation, in the liptako, between the occurrences of molybdenite and a major tectonic discontinuity (Fig. 7). Finally, the nature and low content of these mineralisations, the presence of associated hydrothermal alterations and the nature of the mineralised bodies (granodiorite intrusion), allow the Kourki mineralisation to be linked to the porphyry Mo-Cu type. The major argument in favour of porphyry is the presence of molybdenite in certain samples. Indeed, the presence of molybdenum indicates a relatively large placement depth.

However, in West Africa, several copper mineralisations have been described. In Burkina Faso, there is the $\mathrm{Cu}$-Goren mineralisation located in the greenstone belt of GoromGorom, copper-porphyry of Gaoua located in the GoromGorom belt, and the $\mathrm{Cu}-$ Wayen mineralisation located in the belt Tenkodogo green rocks [8], [30], [36], [43], [52]-[55], [75]. Among these mineralisations, only Gaoua has characteristics similar to that of the study area. Le Mignot et al. [30] performed an absolute dating by the Re-Os method on pyrite and obtained an isochronous age of $2161 \pm 23 \mathrm{Ma}$. This age has been interpreted as the age of formation of Gaoua porphyry. Brownscombe [9] obtained defined ages of $2171.6 \pm 9.3 \mathrm{Ma}$ and $2185.3 \pm 12.0 \mathrm{Ma}$ respectively for the diorite and the gabbro host of Gaoua porphyry through the 
$\mathrm{U} / \mathrm{Pb}$ method. This age is also in agreement with the studies carried out on the magmatic accretion event prior to the
Eburnean orogeny which is dated, according to different authors, between 2250 and $2150 \mathrm{Ma}$ [4], [16].

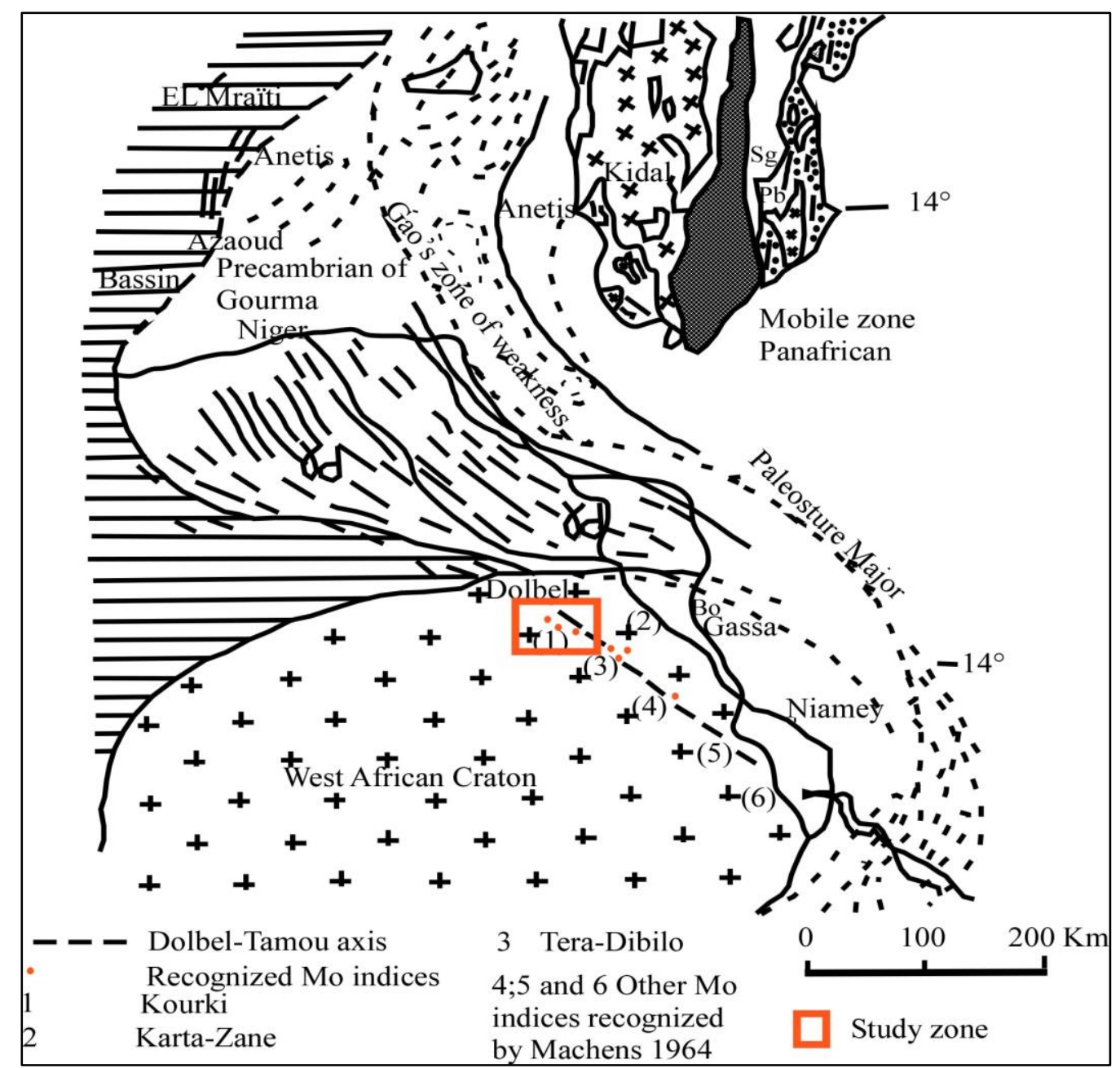

Fig. 7. Regional Geotectonic framework of liptako Molybdenum Indices (geological sketch, modified after Reitchelt [50])

All of these ages are significantly higher than the age obtained at Kourki. The results obtained show that the Kourki $\mathrm{Cu}-\mathrm{Mo}$ mineralisation is of Birimian age. This suggests that the Kourki mineralisation is a Birimian copper porphyry but more recent than Birimian porphyries in West Africa. According to Laznicka [29], porphyry-type deposits of Precambrian age are rare and, moreover, in some cases, their classification remains a subject of debate since deformation and metamorphism generally masked the primary characteristics. Weihed [72] and Wanhainen et al. [71] described these types of deposits in the Fennoscandian shield as porphyry deposits or as hybrid deposits whose characteristics also deserve to be classified as iron-coppergold oxide (IOCG) deposits. According to Wanhainen [70], the Aitik porphyry copper-gold deposit was modified by deformation, metamorphic, magmatic-hydrothermal and IOCG events in several stages. This author concluded that the Aitik deposit is of mixed origin with a major part of copper coming from an old porphyry copper system and a second minor part coming from an IOCG system superimposed. Goodman et al. [19] consider Till (Quebec, Canada) as an Archean porphyry type deposit. Goode [18] demonstrated in the Kivilompolo Au-Mo mineralisation certain number of characters common to Kourki mineralisation. The difference between the two mineralisations in the host rocks is that Kivilompolo is housed in a granito-gneiss while in Kourki the mineralisation is housed in granodiorite. However, there are several examples of mineralised porphyries of Archean and Birimian age in Australia, Scandinavia, India, Namibia and Canada. For the porphyries at Mo, those from Ontario and Finland can be cited which are of Precambrian age (in [20], [46]). The porphyries at $\mathrm{Mo}-\mathrm{Cu}(\mathrm{Ag}-\mathrm{W})$ and at $\mathrm{Mo}-\mathrm{Cu}(\mathrm{W})$ east of Pilbara (Australia) are set up in a bimodal volcanic sequence and their host is a $0.06 \%$ Mo granodiorite and $0.09 \% \mathrm{Cu}$; the $\mathrm{Cu}-\mathrm{Mo}-\mathrm{Au}$ porphyry from Malanjkland, in central India, considered one of the largest deposits in the world $(0.9 \% \mathrm{Cu}, 0.025 \%$ Mo and $0.14 \mathrm{~g} / \mathrm{t} \mathrm{Au})$ shows an age of $2490 \pm 8 \mathrm{Ma}$. The Haib River porphyry in southern Namibia, $\mathrm{Cu}-\mathrm{Mo}$ porphyry $(0.32 \% \mathrm{Cu}$ and $0.10 \% \mathrm{Mo})$ which exhibits an Andean magmatic arc style is dated $~ 2.0 \mathrm{Ga}$.

Finally, there are other types of mineralisation at Mo such as: the skarns at Mo encountered in the carbonate sequences in contact with very differentiated and siliceous intrusions comparable to the intrusions of porphyry at Mo (Mont Laurier in Quebec, [37], [38]); the Ni-Zn-Mo-EGP deposits present in clay shales (thin horizons enriched in pyrite, vaesite $\left(\mathrm{NiS}_{2}\right)$, amorphous jordisite $\left(\mathrm{MoS}_{2}\right)$, sphalerite) in post-Archean orogenic belts. 


\section{Model of $\mathrm{Cu}$ and Mo Mineralisation in the Geodynamic} History of the West African Craton

The age obtained on the Kourki pyrites corresponds to the episode of magmatic accretion $(2.2 \mathrm{Ga}-2.1 \mathrm{Ga})$ which led to the placement of Birimian rocks [39]. This episode takes place upstream of the tectonic phase D1 of the Eburnean orogeny and creates a juvenile Paleoproterozoic crust. This magmatic accretion begins with the installation of tholeitic plumes in an ocean basin, which will form plateaus [2], [7], [59]. The oceanic crust is subducted with the continental crust. This subduction is locally accompanied by calcalkaline volcanism. The island arcs created by this intraoceanic subduction will then come to accrete on the Archean continents (Fig. 8).

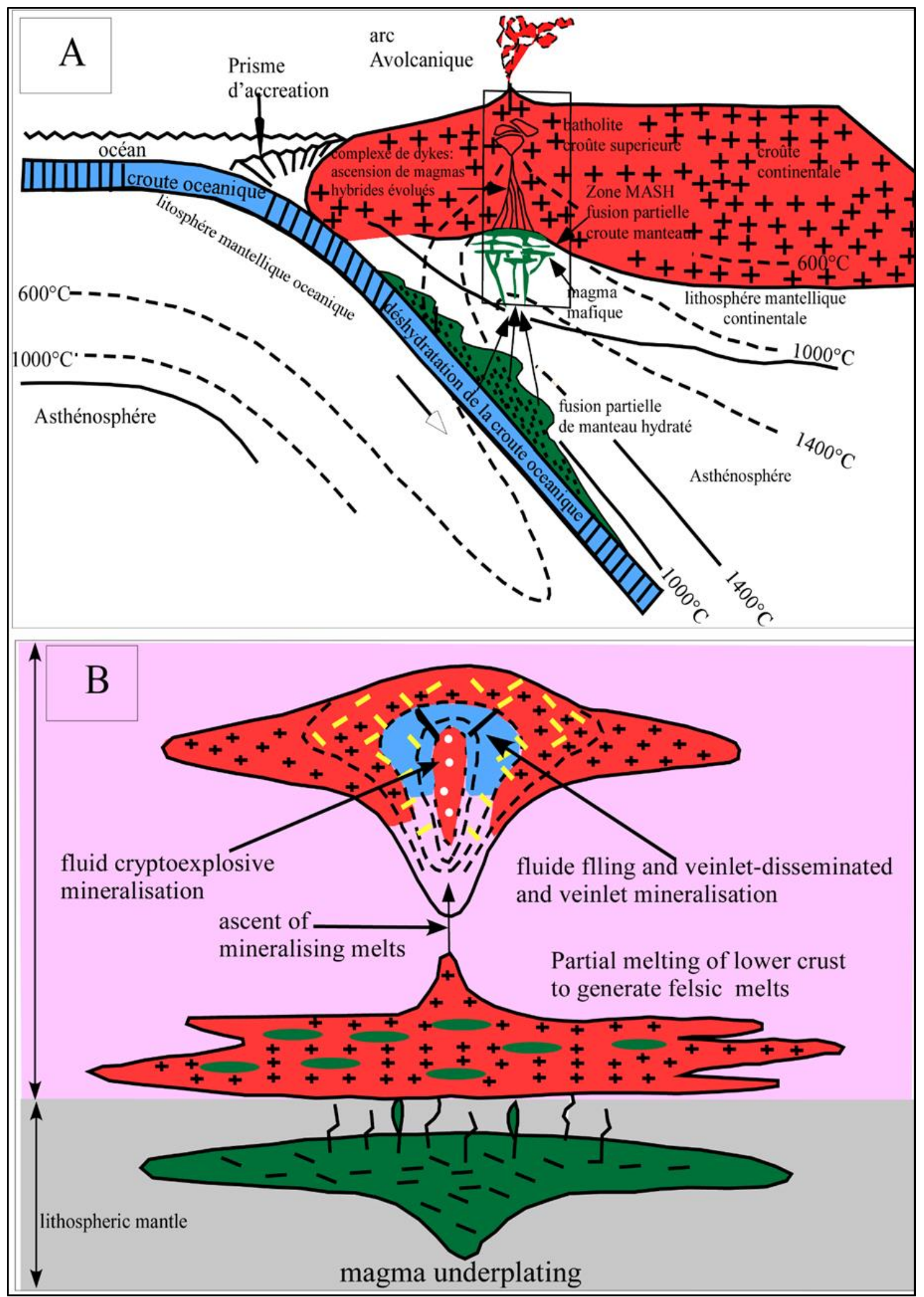

Fig. 8. Diagram of the genesis of magma in the subduction zone (A) (modified after Jébrak and Marcoux [24]) and (B) model proposed for the Kourki CuMo mineralisation. 
The Kourki porphyry system was probably formed as a result of these intra-oceanic subduction phenomena. It was therefore linked to the establishment of granodiorite in the region. Kourki's $\mathrm{Cu}-\mathrm{Mo}$ porphyries were formed from hydrothermal fluids enriched in metals from differentiated and partially crystallized magmas. Two types of hydrothermal fluids are observed: hypersaline fluids (> 26\% $\mathrm{NaCl}$ ) and slightly saline with decreasing temperatures from 600 to $300{ }^{\circ} \mathrm{C}$ [73], [74]. The magmas at the origin of the mineralisations derive its part from the partial fusion of mantle zones metasomatized by the fluids coming from a plate in subduction. The injection of these hot magmas, rich in $\mathrm{S}$ and $\mathrm{Cl}$, in the lower crust will cause the partial fusion of this one, causing the formation of hybrid magmas. The area where this tiered fusion takes place is called the Melting Assimilation Storage Homogeneization (MASH) area. The rise of these magmas and their evolution by fractional crystallization and assimilation will be at the origin of the diversity of composition of the various granite porphyries at Kourki. The genesis of Kourki's $\mathrm{Cu}$-Mo porphyry system would be associated with the fluids which separate from the silicate liquid at the end of crystallization. The fluids thus formed would accumulate over a prolonged period, in the summit part of the chamber; when the fluid pressure of the magma exceeds the lithostatic pressure, there will be fracturing and brecciation of the surrounding, expulsion of the fluids and formation of a dome consisting of a swarm of dykes and a mineralised stockwork (Fig. 8A). The decrease in fluid pressure linked to the opening of the fractures and the drop in temperature will cause it to boil.

The departure of the ligands, in particular the Sulphide in the vapour phase, will induce the precipitation of the metals and give the mineralised stockwork to the roof of the Kourki batholith in association with the supersalted liquid phase (from 30 to $50 \%$ eq. $\mathrm{NaCl}$ weight) dense called brine; potassium alteration is associated with this mineralised zone [51], [56]. The porphyry representing an important source of heat, will induce the formation of convective hydrothermal cells of the intraformational waters which leach the host rocks and are also charged in metals. Acid fluids from the vapour phase, of low density, can mix with these meteoric fluids and give rise to phyllitic and argillic alterations and to a second generation of mineralisation associated with zones rich in pyrite. Molybdenum is reported to be transported as hydroxylated complexes in these low-salt fluids [13]. In fact, this context provides an environment favourable to the production of alkaline calcium magma and the formation of porphyry. The deposits were therefore set up in an oceanic context of an island arc and found themselves in the continental domain during the tectonic accretion against the Archean lands which took place during phase D1 of the Eburnean orogeny.

This model of Kourki porphyry formation is entirely compatible with the nature of the host rocks studied. In addition, its installation in the oceanic domain could explain on the one hand the alteration zones, and on the other hand the presence of gabbro observed locally on the ground.

\section{CONCLUSION}

Under this work, the Kourki mineralisation was characterised as being porphyritic in nature. The host rock pyrites of the $\mathrm{Cu}$-Mo mineralisation have been absolutely dated by the Re-Os isotopic system. This dating provided ages ranging between $2110 \pm 51 \mathrm{Ma}$ and $2158 \pm 51 \mathrm{Ma}$. These ages make it possible to associate the formation of the $\mathrm{Cu}-\mathrm{Mo}$ porphyry of Kourki with the episode of magmatic accretion which precedes the Eburnean orogeny, and it would be formed following a phenomenon of subduction between the oceanic crust and the continental crust. It is the Birimian $\mathrm{Cu}$ Mo porphyry system of Kourki which constitutes an exception for these deposits which are generally much younger. Its good preservation is, moreover, a proof of the stability of the West African Craton since the Eburnean orogeny. Finally, the Kourki $\mathrm{Cu}-\mathrm{Mo}$ porphyry dating provided a new geochronological constraint on the volcanism parameter of the arc preceding the Eburnean orogeny in the Gorouol greenstone belt.

\section{ACKNOWLEDGEMENT}

This work was funded by Pan African University of Life and Earth Sciences Institute (PAULESI) and received logistical support from University of Abdou Moumouni (UAM) of Niger. The authors are much grateful to PAULESI and UAM.

\section{REFERENCES}

[1] A. Abdou, H. Bonnot, D. Bory Kadey, D. Chalamet, M. Saint Martin et I. Younfa, "Notice explicative des cartes géologiques du liptako à $1 / 100000$ et 1/200 000, Ministère des Mines et de la géologie," Rép. Niger 64p., 1998.

[2] W. Abouchami, M. Boher, A. Michard, and F. Albarède, "A major 2.1 Ga event of mafic magmatism in West Africa: an early stage of crustal accretion," Journal of Geophysical Research, vol. 95, no. B11, pp. 17605-17629, Oct. 1990

[3] I. Ama Salah, J. P. Liégeois, et A. Pouclet, "Evolution d'un arc insulaire océanique birimien précoce au Liptako nigérien (Sirba): géologie, géochronologie et géochimie," Journal of African Sciences, vol. 22, pp 235-254, 1996

[4] L. Baratoux, V. Metelka, S. Naba, M. W. Jessell, M. Grégoire, and J. Ganne, "Juvenile Paleoproterozoic crust evolution during the Eburnean orogeny ( 2.2-2.0 Ga), Western Burkina-Faso," Precambrian Research, vol. 191, no. 1-2, pp. 18-45, Nov. 2011.

[5] L. Baratoux, V. Metelka, S. Naba, P. Ouiya, L. Siebenaller, M.W. Jessell, A. Naré, S. Salvi, D. Beziat, and G. Franceschi, "Tectonic evolution of the Gaoua region, Burkina Faso: Implications for mineralization," Journal of African Earth Sciences, vol. 112, pp. 419 439, Dec. 2015.

[6] R. Black, "Precambrian of West Africa," Episodes Journal of International Geoscience, vol. 3, no. 4, pp. 3-8, Dec. 1980.

[7] M. Boher, W. Abouchami, F. Albarède, and N. T. Arndt, "Crustal growth in West Africa at 2.1 Ga," Journal of Geophysical Research: Solid Earth, vol. 97, no. B1, pp. 345-369, Jan. 1992.

[8] J. Bouladon, J. Marcelin, and A. Papon, "Les minéralisations en cuivre et molybdène liées aux porphyrites post-ophiolitiques du Birrimien," in Les Roches Plutoniques dans leurs rapports Avec les gîtes minéraux, (Paris: Morin, P.), 1973, pp. 291-296.

[9] W. Brownscombe, "The Tinga anomaly: A new style of gold mineralization in Ghana?" Unpublished MSc thesis, University of Oxford, $80 \mathrm{p}$.

[10] O. Cardon, "Datation Re-Os sur pyrite et traçage des sources des métaux dans des gisements de type pophyre et épithermal neutre: Exemple des gisements de Bolcana, Troita et Magura, Monts Apuseni, Roumanie. Thèse Université Nancy I, 2007, 233 p.

[11] O. Cardon, L. Reisberg, A. S. André-Mayer, J. Leroy, V. Milu, and C. Zimmermann, "Re-Os systematics of pyrite from the Bolcana porphyry coopper deposit, Apuseni Mountains, Romania," Economic Geology, vol. 103, no. 8, pp. 1695-1702, Dec. 2008. 
[12] C. Castaing, M. Bila, J. P. Milési, D. Thiéblemont, J. Le Metour, E. Egal, M. Donzeau, C. Guerrot, A. Cocherie, P. Chevremont, I. Teygey, Y. Itard, B. Zida, I. Ouédraogo, S. Koté, B. E. Kaboré, C. Ouédraogo, J. C. Ki, and C. Zunino, "Notice explicative de la carte géologique et minière du Burkina Faso à 1/1000 000," 3ème édition, 2003. 148 p.

[13] J. S. Cline, and D. A. Vanko, "Magmatically generated saline brines related to molybdenum at Questa, New Mexico, USA," Chapter 8 in Magma, fluids and ore deposits, J.F.H. Thompson editor, Mineralogical Association of Canada, short course, vol. 23, pp. 153$174,1995$.

[14] M. Cuney, and A. Autran, "Géologie profonde de la France. Forage scientifique d'Echassières. Une clé pour la compréhension des mécanismes magmatiques et hydrothermaux associés aux granites à métaux rares. Géologie de la France, vol. 23, pp. 1-35, 1987.

[15] D. W. Davis, W. Hirdes, U. Schaltegger, and E. A. Nunoo, "U-Pb age constraints on deposition and provenance of Birimian and gold-bearing Tarkwaian sediments in Ghana, West Africa," Precambrian. Research, vol. 67, no. 1-2, pp. 89-107, Mar. 1994.

[16] J. L. Feybesse, M. Billa, C. Guerrot, E. Duguey, J. L. Lescuyer, J. P. Milesi, and V. Bouchot, "The paleoproterozoic Ghanaian province: Geodynamic model and ore controls, including regional stress modelling," Precambrian Research, vol. 149, no. 3-4, pp. 149-196, Sep. 2006.

[17] S. H. Garba, M. Konaté, A. Yacouba, et A. Soumaïla, "Les minéralisations de manganèse du Nord Téra (Liptako, Ouest Niger) origine et conditions de mise en place," REV. CAMES - vol. 5 no. 2 , $15 p ., 2017$

[18] M. Goode, "Mineralogy and geochemistry of the Kivilompolo Molybdenum mineralisation in the Peräpohja belt, northern Finland,' p. 57, 2019.

[19] S. Goodman, A. E. Williams-Jones, and P. Carles, "Structural controls on the Archean Troilus gold-copper deposit, Quebec, Canada. Economic Geology, vol. 100, no. 3, pp. 577-582, May 2005

[20] N. A. Goryachev, and F. Pirajno, "Gold deposits and gold metallogeny of Far East Russia," Ore Geology Reviews, vol. 59, pp. 123-151, Jun. 2014.

[21] M. Gueye, A. M. Van den Kerkhof, U. F. Hein, M. Diene, A. Mucke, and S. Siegesmund, "Structural control, fluid inclusions and cathodoluminescence studies of Birimian gold-bearing quartz vein systems in the Paleoproterozoic Mako belt, southeastern Senegal,' South African Journal of Geology, vol. 116, no. 2, pp. 199-218, Dec. 2013.

[22] M. Gueye, P. M. Ngom, M. Diène, Y. Thiam, S. Siegesmund, K Wemmer, and S. Pawlig, S, "Intrusive rocks and tectono-metamorphic evolution of the Mako Paleoproterozoic belt (Eastern Senegal, West Africa)," Journal of African Earth Sciences, vol. 50, no. 2-4, pp. 88 110, Feb. 2008

[23] W. Hirdes, D. W. Davis, "U-Pb geochronology of paleoproterozoic rocks in the southern part of the Kedougou-Kéniéba Inlier, Senegal, West Africa: evidence for diachronous accretionary development of the Eburnean province," Precambrian Research, vol. 118, no. 1-2, pp. 83 99, Sep. 2002.

[24] M. Jébrak, É. Marcoux, “Québec (Province). Ministère des ressources naturelles et de la faune, Québec G. Géologie des ressources minerals,' Ministère des ressources naturelles et de la faune; 2008.

[25] M. W. Jessell, P. O. Amponsah, L. Baratoux, D. K. Asiedu, G. K. Loh, and J. Ganne, "Crustal-scale transcurrent shearing in paleoproterozoic Sefwi-Sunyani-Comoe region, West Africa," Precambrian Research, vol. 212, pp. 155-168, Aug. 2012.

[26] M. Konaté, Y. Ahmed, A. Gärtner, D. A. Amadou, H. I. Maharou, K. Tourba, M. Hofmann, J. Zieger, U. Linnemann, “U-Pb detrital zircon ages of sediments from the Firgoun and Niamey areas (eastern border of West African Craton, West Niger)," Comptes Rendus Geoscience, vol. 350, no. 6, pp. 267-278, Sep. 2018.

[27] A. N. Kouamelan, C. Delor, J. J. Peucat, M. Ballèvre, S. Doumbia, et J. Camil, "Influence significative du Birimien sur le domaine Archéen de la Côte d'Ivoire," Séance Spéc. Soc. Géol. Fr., " Géodynamique du Paléoprotérozoïque », Orléans, vol. 17, p. 21, Nov. 1995.

[28] I. Kusnir, H. Sylwestrazak, et V. Zajaczkowsky, "Rapport sommaire sur les travaux des recherches sur l'indice de Mo-Cu de Kourki effectués jusqu'au 1er Juin, Recherches minières dans deux zones. Rapport PNUD nOP-EXREP-B-5/19, Niamey, 1971.

[29] P. Laznicka, "Giant metallic deposits: Future sources of industria metals," Springer Science \& Business Media, p. 732, Jun. 2006.

[30] E. Le Mignot, L. Siebenaller, D. Béziat, S. Salvi, A. S. André-Mayer, L. Reisberg, G. Velásquez, C. Zimmermann, and G. Franceschi, "The paleoproterozoic copper-gold deposit of Gaoua, Burkina Faso: evidence for a superimposition of a porphyry copper with an orogenic gold deposit. Economic Geology Special Issue article - West Africa, 2015.

[31] A. Leube, W. Hirdes, R. Mauer, and G. O. Kesse, "The early Proterozoic Birimian Supergroup of Ghana and some aspects of its associated gold mineralisation," Precambrian Research, vol. 46, no. 1-2, pp.139-165, Jan. 1990.

[32] M. Lompo, Geodynamic evolution of the 2.25-2.0 Ga Palaeoproterozoic magmatic rocks in the Man-Leo Shield of the West African Craton. A model of subsidence of an oceanic plateau, Geological Society, London, Special Publications, Jan. 2009, vol. 323, no. 1, pp. 231-54.

[33] M. Lompo, "Paleoproterozoic structural evolution of the Man-Leo Shield (West Africa). Key structures for vertical to transcurrent tectonics," Journal of African Earth Sciences, vol. 58, no. 1, pp. 19-36, Aug. 2010.

[34] E. Machens, "Mission de prospection générale du liptako, rapport de fin de mission (1958-1964) et inventaire d'indice de minéralisation. B.R.G.M; 74, Rue de la fédération Paris XVe.” pp. 81-84, 1964

[35] E. Machens, "Contribution à l'étude des formations du socle cristallin et de la couverture sédimentaire de l'Ouest de la République du Niger,' Ed. BRGM; 1973

[36] J. Marcelin, "Notice explicative de la carte géologique au 1/200000 Gaoua-Batié. Édition,” BRGM, Orléans. 1971.

[37] L. D. Meinert, "Skarns and skarn deposits," Geoscience Canada, vol. 19, pp. 145-162, 1992

[38] L. D. Meinert, D. R. Lentz, and R. J. Newberry, "Special issue devoted to skarn deposits," Economic Geology, vol. 95, pp. 1183-1370, 2000.

[39] J. P. Milesi. Métallogénie comparée des provinces métallifères paléoprotérozoïques: synthèses métallogéniques et potentiels métallifères. Université de Lyon I. 2001.

[40] J. P. Milési, J. L. Feybesse, P. Ledru, A. Dommanget, M. F. Ouedraogo, E. Marcoux, A. Prost, C. Vinchon, J. P. Sylvain, and V. Johan (1989) West African gold deposits in their lower Proterozoic lithostructural setting. Chroniques de La Recherche Minière France 3-98.

[41] J. P. Milési, J. L. Feybesse, P. Pinna, Y. Deschamps, H. Kampunzu, S. Muhongo, J. L. Lescuyer, E. Le Goff, C. Delor, M. Billa, and F. Ralay. Geological map of Africa 1: 10,000,000, SIGAfrique project. In20th conference of African geology, BRGM, Orléans, France 2004 Jun (pp 2-7)

[42] S.I. Nakai, A. N. Halliday, S. E. Kesler, and H. D. Jones, "Rb-Sr dating of sphalerites from Tennessee and the genesis of Mississippi Valley type ore deposits," Nature, vol. 346, no. 6282, pp. 354-357, Jul. 1990.

[43] M. Ouedraogou. Carte des gîtes et indices minéraux du Burkina Faso 1/1 000 000. Ouagadougou, Burkina Faso: Bureau des Mines et de la Géologie du Burkina (BUMIGEB). 1991.

[44] S. Pawlig, M. Gueye, R. Klischies, S. Schwarz, K. Wemmer, and S. Siegesmund, "Geochemical and $\mathrm{Sr}-\mathrm{Nd}$ isotopic data on the Birimian of the Kedougou-Kenieba inlier (eastern Senegal): Implications on the Palaeoproterozoic evolution of the West African craton," South African Journal of Geology, vol. 109, no. 3, pp. 411-427, Sep. 2006.

[45] T. Petke, and L. W. Diamond, "Rb-Sr dating of sphalerite based on fluid inclusion-host mineral isochrons; a clarification of why it works," Economic Geology, vol. 91, no. 5, pp. 951-956, Aug. 1996

[46] F. Pirajno, (2009). Hydrothermal processes and Mineral Systems, Geological Survey of Western Australia, Perth, WA, Autralia. Ed Springer, 2009, 1250p

[47] J. Pons, P. Barbey, D. Dupuis, and J. M Léger, "Mechanisms of pluton emplacement and structural evolution of a 2.1 Ga juvenile continental crust: the Birimian of southwestern Niger," Precambrian Research vol. 70, vol. 3-4, pp. 281-301, Jan. 1995.

[48] A. Pouclet, M. Vidal, C. Delor, Y. Simeon, et G. Alric, "Le volcanisme birimien du nord-est de la Cote-d'Ivoire, mise en evidence de deux phases volcano-tectoniques distinctes dans l'evolution geodynamique du Paleoproterozoique," Bulletin de la Société géologique de France, vol. 67, no. 4, pp. 529-541, Jul. 1996

[49] C. Ranc (1975). Mission de sondages Kourki. - Rapport de campagne 1974-1975. Rapp. PNUD/Niamey. p. 38

[50] R. Reitchelt (1972). Géologie du Gourma. Mémoire du DRGM n53, PP 216-302.

[51] E. Seedorff, J. H. Dilles, J. M. Proffett, M. T. Einaudi, L. Zurcher, W J. A. Stavast, D. A. Johnson, and M. D. Barton, "Porphyry-related deposits: Characteristics and origin of hypogene features," Economic geology, 100th Anniversary volume, pp. 251-298, 2005.

[52] R. Sillitoe, "Some thoughts on gold-rich porphyry copper deposits," Mineralium Deposita, vol. 14, no. 2, pp. 161-174, Aug. 1979.

[53] R. H. Sillitoe, "Iron oxide-copper-gold deposits: an Andean view," Mineralium Deposita, vol. 38, no. 7, pp. 787-812, Oct. 2003. 
[54] R. H. Sillitoe. An appraisal of Dienemera and Gongondy copper-gold prospects, Gaoua district, Burkina Faso. Unpublished report for Wentworth Resources Pty Ltd. 2007.

[55] R. H. Sillitoe, "Porphyry copper systems," Economic geology, vol. 105, no. 1, pp. 3-41, Jan. 2010.

[56] W. D. Sinclair (2007). Porphyry deposits, in Goodfellow, W.D., ed, Mineral deposits of Canada: A synthesis of Major Deposit-types, District Metallogeny, the Evolution of Geological Provinces and Exploration Methods: Geological Association of Canada, Mineral deposits Division, Special Publication N5, pp. 223-243.

[57] M. I. Smoliar, R. J. Walker, and J. W. Morgan, "Re-Os ages of group IIA, IIIA, IVA, and IVB iron meteorites," Science, vol. 271, no. 5252, pp. 1099-1102, Feb. 1996.

[58] Soumaila A. (2000). Etude structurale, pétrographique et géochimique de la ceinture de Diagorou-Darbani, Liptako, Niger Occidental (Afrique de l'Ouest). Thèse, Univ. Franche-Comté, 253p. Soumaila A. Etude structurale, pétrographique et géochimique de la ceinture birimienne de Diagorou-Darbani Liptako, Niger occidental (Afrique de l'ouest) (Doctoral dissertation, Besançon).

[59] A. Soumaila, P. Henry, Z. Garba, M. Rossi, "REE patterns, Nd-Sm and $\mathrm{U}-\mathrm{Pb}$ ages of the metamorphic rocks of the Diagorou-Darbani greenstone belt (Liptako, SW Niger): implication for Birimian (Palaeoproterozoic) crustal genesis," Geological Society, London, Special Publications, vol. 297, no. 1, pp. 19-32, Jan. 2008.

[60] A. Soumaila, P. Henry, et M. Rossy, "Contexte de mise en place des roches basiques de la ceinture de roches vertes birimienne de DiagorouDarbani (Liptako, Niger, Afrique de l'Ouest): plateau océanique ou environnement d'arc/bassin arrière-arc océanique," Comptes Rendus Geoscience, vol. 336, no. 13, pp. 1137-1147, Oct. 2004.

[61] Soumaila, A., Konaté M. (2005). Caractérisation de la déformation dans la ceinture birimienne (paléoprotérozoïque) de Diagorou-Darbani (Liptako nigérien, Afrique de l'Ouest). Afr. Geo. Revew., vol. 13, no. 3, pp 161-178.

[62] Stein HJ. 13.4 Dating and Tracing the History of Ore Formation. Treatise on Geochemistry (second edition). Oxford, Elsevier. 2014:87118

[63] Tapsoba B, Lo CH, Jahn BM, Chung SL, Wenmenga U, Iizuka Y. Chemical and $\mathrm{Sr}-\mathrm{Nd}$ isotopic compositions and zircon $\mathrm{U}-\mathrm{Pb}$ ages of the Birimian granitoids from NE Burkina Faso, West African Craton Implications on the geodynamic setting and crustal evolution. Precambrian Research. 2013 Jan 1; 224:364-396.

[64] Thiéblemont D. (2004). Genèse de la croûte continentale en Afrique de 1'Ouest à l'Archéen : une approche "régionale et systématique ». Habilitation à Diriger des Recherches, $149 \mathrm{p}$.

[65] Trompette R. (1997), "Neoproterozoic ( 600 Ma) aggregation of Western Gondwana : a tentative scenario", Precambrian Research, vol. 82, pp. 101-112. Trompette R. Neoproterozoic ( 600 Ma) aggregation of Western Gondwana: a tentative scenario. Precambrian Research. 1997 Mar 1;82(1-2):101-12.

[66] Tshibubudze A, Hein KA. Gold mineralisation in the Essakane goldfield in Burkina Faso, West African craton. Ore Geology Reviews. 2016 Oct 1; 78:652-9.

[67] Tshibubudze A, Hein KA, Peters LF, Woolfe AJ, McCuaig TC. Oldest $\mathrm{U}-\mathrm{Pb}$ crystallisation age for the West African Craton From the Oudalan-Gorouol Belt of Burkina Faso. South African Journal of Geology. 2013 Jun 1;116(1):169-81.

[68] Tshibubudze A, Hein KA, Marquis P. The Markoye Shear Zone in NE Burkina Faso. Journal of African Earth Sciences. 2009 Dec 1;55(5):245-56.

[69] Pouclet A, Vidal M, Delor C, Simeon Y, Alric G. Le volcanisme birimien du nord-est de la Cote-d'Ivoire, mise en evidence de deux phases volcano-tectoniques distinctes dans l'evolution geodynamique du Paleoproterozoique. Bulletin de la Société géologique de France. 1996 Jul 1;167(4):529-41.

[70] Wanhainen, C. (2005). On the origin and evolution of the Palaeoproterozoic Aitik Cu-Au-Ag deposit, Northern Sweden. PhD thesis. Lulea University of Technology.

[71] Wanhainen $\mathrm{C}$, Broman $\mathrm{C}$, Martinsson O. The Aitik $\mathrm{Cu}-\mathrm{Au}-\mathrm{Ag}$ deposit in northern Sweden: a product of high salinity fluids. Mineralium Deposita. 2003 Sep 1;38(6):715-726.

[72] Weihed P. A review of Palaeoproterozoic intrusive hosted $\mathrm{Cu}-\mathrm{Au}-\mathrm{Fe}-$ oxide deposits in northern Sweden.

[73] White WH, Bookstrom AA, Kamilli RJ, Ganster MW, Smith R, Ranta DE, Steininger RC. Character and origin of Climax-type molybdenum deposits. Economic Geology. 1981; 75:270-316.

[74] White A, Burgess R, Charnley N, Selby D, Whitehouse M, Robb L, Waters D. Constraints on the timing of late-Eburnean metamorphism, gold mineralisation and regional exhumation at Damang mine, Ghana. Precambrian Research. 2014 Apr 1; 243:18-38.

[75] Zeegers, H., Goni, J., and Wilhelm, E. (1981). Geochemistry of lateritic profiles over a disseminated Cu-Mo mineralization in Upper Volta (West Africa)-preliminary results. In Lateritization Processes, (Rotterdam), pp. 359-368.

[76] Zhang J, Linnen R, Lin S, Davis D, Martin R. Paleoproterozoic hydrothermal reactivation in a Neoarchean orogenic lode-gold deposit of the southern Abitibi subprovince: U-Pb monazite geochronological evidence from the Young-Davidson mine, Ontario. Precambrian Research. 2014 Aug 1; 249:263-72. 